\title{
Accuracy of linear measurements performed with two imaging software in cone-beam computed tomography scans of dry human mandibles
}

\author{
ALESSANDRO A.L.S. SILVA ${ }^{1,4}$, ADEMIR FRANCO ${ }^{2}$, ÂNGELA FERNANDES ${ }^{2}$, CLAUDIO \\ COSTA $^{3}$, JORGE S. BARBOSA ${ }^{3}$ and FERNANDO H. WESTPHALEN ${ }^{1,2}$ \\ ${ }^{1}$ Departamento de Odontologia, Escola de Ciências da Vida, Pontifícia Universidade Católica do Paraná/ \\ PUCPR, Rua Imaculada Conceição, 1155, Prado Velho, 80215-901 Curitiba, PR, Brazil \\ ${ }^{2}$ Departamento de Estomatologia, Universidade Federal do Paraná/UFPR, Av. Lothário \\ Meissner, 632, Jardim Botânico, 80210-170 Curitiba, PR, Brazil \\ ${ }^{3}$ Departamento de Estomatologia, Universidade de São Paulo/USP, Av. Professor \\ Lineu Prestes, 2227, Butantã, 05508-000 São Paulo, SP, Brazil \\ ${ }^{4}$ Departamento de Educação Tecnológica, Centro Universitário de Várzea Grande/UNIVAG, \\ Av. Dom Orlando Chaves, 2655, Cristo Rei, 78118-900 Várzea Grande, MT, Brazil \\ Manuscript received on March 24, 2017; accepted for publication on May 30, 2017
}

\begin{abstract}
The present study aimed to assess the accuracy of linear measurements performed with two software packages in multislice (MSCT) and cone beam (CBCT) computed tomography (CT) images. The sample consisted of 10 human mandibles marked standardly 8 times with metallic orthodontic wires. The mandibles underwent both MSCT and CBCT scanning and were measured linearly and digitally with two software packages, namely Studio $3.1^{\circledR}$ (Anne Solutions ${ }^{\circledR}$, SP, Brazil) (ST) and Implant Viewer $2.817^{\circledR}$ (Anne Solutions ${ }^{\circledR}$, SP, Brazil) (IV). The linear measurements were the mandibular height $(\mathrm{MH})$ and width (MW), and the distance from the alveolar ridge to the mandibular canal (AC). To validate the measurements, the mandibles were sectioned in the marked regions and measured with a digital caliper. Statistically significant differences were not observed between the measurements (MH, MW, and AC) taken digitally with the two software packages from images obtained from the two scanning modalities (MSCT and CBCT) and the measurements taken manually with a digital caliper ( $p>0.05$ ). MSCT and CBCT images measured digitally with ST and IV software packages resulted in reliable outcomes when compared to measurements obtained manually. Both software and imaging modalities are reliably useful for planning surgical procedure in the dental practice.
\end{abstract}

Key words: computed tomography, dental implant, morphology, radiology.

\section{INTRODUCTION}

Success of dental implant surgeries is partially assured by guidelines for the selection and

Correspondence to: Alessandro Augusto Lopes Santana Silva E-mail: alessandrolopessantana@gmail.com application of maxillofacial imaging. Currently, computed tomography (CT) is the method most used for planning dental implant surgeries, as the limitations of conventional radiographs include the lack of detailed information on bone thickness 
(Parnia et al. 2010). In CT imaging, maxillofacial hard tissues are captured by a sensor and manipulated three-dimensionally to avoid overlapping structures and to facilitate image interpretation (Frederiksen 1995). In the field of CT, multislice (MSCT) and cone-beam (CBCT) modalities figure more often in Medicine and Dentistry, respectively. Specifically, MSCT may be used in Medicine from the integral exam of the living (Deniz et al. 2017, Peng et al. 2016) to the cadaveric investigations on the cause of death and human identification (Puentes et al. 2009, Bolliger et al. 2005, 2007). On the other hand, CBCT is used in Dentistry for oral diagnosis (Larheim et al. 2015), investigation of dental and facial trauma (Palomo and Palomo 2009), guided surgeries (Deguchi et al. 2006, Garcia et al. 2008) pathological dissemination of dental lesions (Selden 1999, Obayashi et al. 2004), and planning of prosthetic rehabilitation (Dreiseidler et al. 2012, Tejaswi and Periya 2013).

Previous studies highlight the advantages of CBCT imaging in face of MSCT, such as the use for less radiation and potentially higher resolution for images on dental and maxillofacial structures (Moura et al. 2009). Additionally, MSCT is designed mainly for full-body scans and requires larger and more expensive systems and facilities. Several studies have compared the accuracy of linear measurements (Pinsky et al. 2006, Gulobovic et al. 2012) between different CT modalities (Lund et al. 2009, Primo et al. 2012, Kim et al. 2012). In general, CBCT and MSCT perform similarly and accurately for linear measuring (Freire-Maia et al. 2017). However, these studies focused on comparing measurements taken digitally and manually without scoping deeper on the potential bias associated with the software packages used for image manipulation and analysis.

The present study aimed to assess the accuracy of linear measurements comparing two software packages in MSCT and CBCT scans of dry human mandibles.

\section{MATERIALS AND METHODS}

The present study was approved by the local Committee of Ethics in Research (protocol: \#679.794).

\section{STUDY DESIGN AND SAMPLING}

A retrospective, cross-sectional and observational study was conducted. The sample consisted of 10 edentulous dry human mandibles. Each mandible was fixed in a parallelometer (B2-Bio-Art ${ }^{\circledR}$, Bio-Art Equipamentos Odontológicos Ltd. ${ }^{\circledR}$, São Paulo, SP, Brazil) with dental wax (Wilson Polidental ${ }^{\circledR}$, Cotia, SP, Brazil). The mandible bodies were marked 8 times with vertical linear drawings (4 marks in the posterior region and 4 marks in the anterior region) of $0.5 \mathrm{~mm}$ thickness. The marks were performed with a prosthetic delineator crossing entirely the mandible border to simulate the parallelism of CT and MSCT scans. Orthodontic wire (Orthodontic Strong Elastic Floss CrNi floss ${ }^{\circledR}$, Morelli ${ }^{\circledR}$, Sorocaba, SP, Brazil) of $0.3 \mathrm{~mm}$ thickness was bonded over each vertical mark using cyanoacrylate ester (Loctite 495 Super Bonder Instant Adhesive ${ }^{\mathbb{R}}$, Düsseldorf, Germany) (Figure 1). Small grooves were made on the orthodontic wire with diamond burs (FKG $1011 \mathrm{HL}^{\circledR}$, Pdx Point Diamond Ind. Com. Ferram. Odontológ. Ltd. ${ }^{\circledR}$, Terra Preta, SP, Brazil) and a high-speed handpiece (Silent MRS $400^{\circledR}$, Dabi Atlante ${ }^{\circledR}$, Ribeirão Preto, SP, Brazil), without irrigation, to mark 4 points distributed in the vestibular/buccal, lingual, upper and lower surfaces of the mandible. These grooves were considered reference points for further measurements directly in the mandible and in CBCT/MSCT images.

\section{METHODOLOGY}

The mandibles underwent CBCT scanning with an i-CAT 17-19 system $^{\circledR}$ (Imaging Sciences International LLC ${ }^{\circledR}$, Hatfield, PA, USA) at $120 \mathrm{kV}$, $8 \mathrm{~mA}$, rotation of $360^{\circ}, 0.25 \mathrm{~mm}$ voxel size, and acquisition time of 8.9 seconds. MSCT scanning 

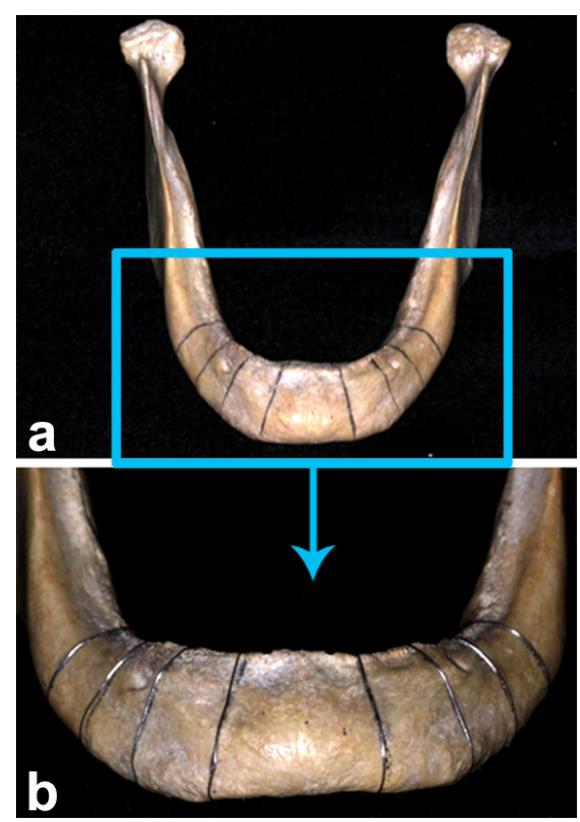

Figure 1 - Dry human mandible marked prior to scanning and measuring procedures. Edentulous mandible body marked 8 times with prosthetic delineator (a) and orthodontic wire (b).
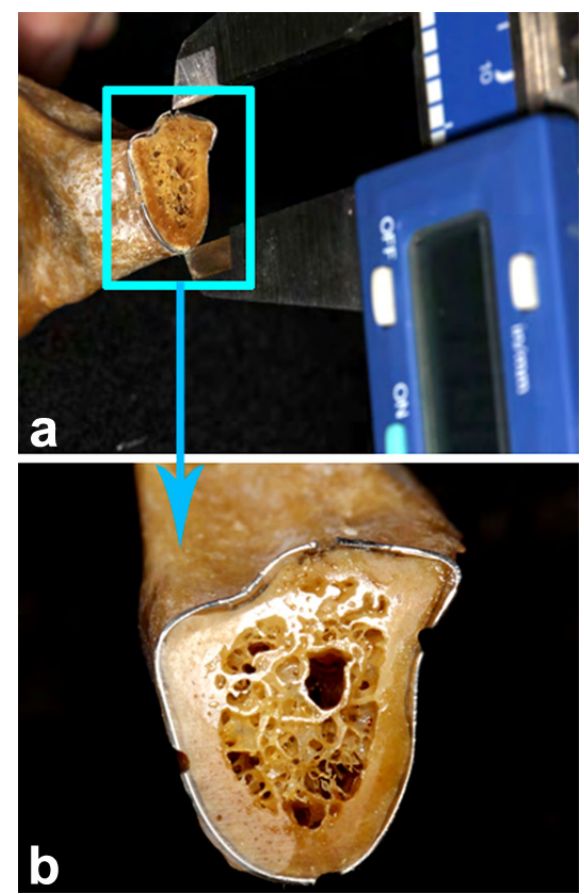

Figure 2 - Dry human mandible manually measured. High of the mandible body measured with a digital caliper (a) in the region previously marked with orthodontic wire and cut with diamond burs (b). was performed using a Philips Mx8000 IDT $16 \mathrm{CT}^{\circledR}$ device (Philips Medical System ${ }^{\circledR}$, Amsterdam, The Netherlands) with $120 \mathrm{kV}, 150 \mathrm{~mA}$, collimation of $16^{\prime} 0.6 \mathrm{~mm}$, thickness of $0.5 \mathrm{~mm}$, resolution of 0.4 ' $0.4 \mathrm{~mm}$ and acquisition time of 5 seconds. The mandibles were scanned considering their basal surface as standard parameter. Stabilization during the image acquisition was achieved using a $50 \mathrm{~mm}$ Styrofoam plate.

To establish a reference measurement, the mandibles were sectioned after CT scanning allowing gold-standard measurements. The section were performed adjacent to the orthodontic wire marks with a low-speed metallic saw (EXTEC Labcut $1010^{\circledR}$, Emfield, CT, USA) mounted with a $76^{\prime} 0.2 \mathrm{~mm}$ blade (11-10066 IsoMet Wafering Blades $15 \mathrm{HC}^{\circledR}$, Buehler ITW ${ }^{\circledR}$, Lake Bluff, IL, USA) under constant irrigation and general rotation of 500rpm (limit of the machine). The sectioned regions underwent polishing (EcoMet 3000 Grinder $^{\circledR}$, Buehler ITW ${ }^{\circledR}$, Lake Bluff, IL, USA) until reaching the exact position of the orthodontic wire and their corresponding marks.

After polishing, direct measurements were performed in the surface sectioned using a digital caliper (Mitutoyo Series 500-144 ${ }^{\circledR}$, Absolute $^{\circledR}$, Suzano, SP, Brazil) (Figure 2). Apart direct measurements, digital measurements were performed importing the CT images in Imaging Studio $^{\circledR}$ (Anne Solutions ${ }^{\circledR}$, São Paulo, SP, Brazil) and Implant Viewer ${ }^{\circledR}$ (Anne Solutions ${ }^{\circledR}$, São Paulo, SP, Brazil) software packages (Figure 3).

\section{DATA ANALYSIS}

In both software packages, the linear measurements were performed over the parasagittal images. In the posterior region, these measurements consisted of the height and width of the mandible, and distance from the alveolar ridge to the mandibular canal. In the anterior region, the height and width of the mandible were considered. The high of the mandible 

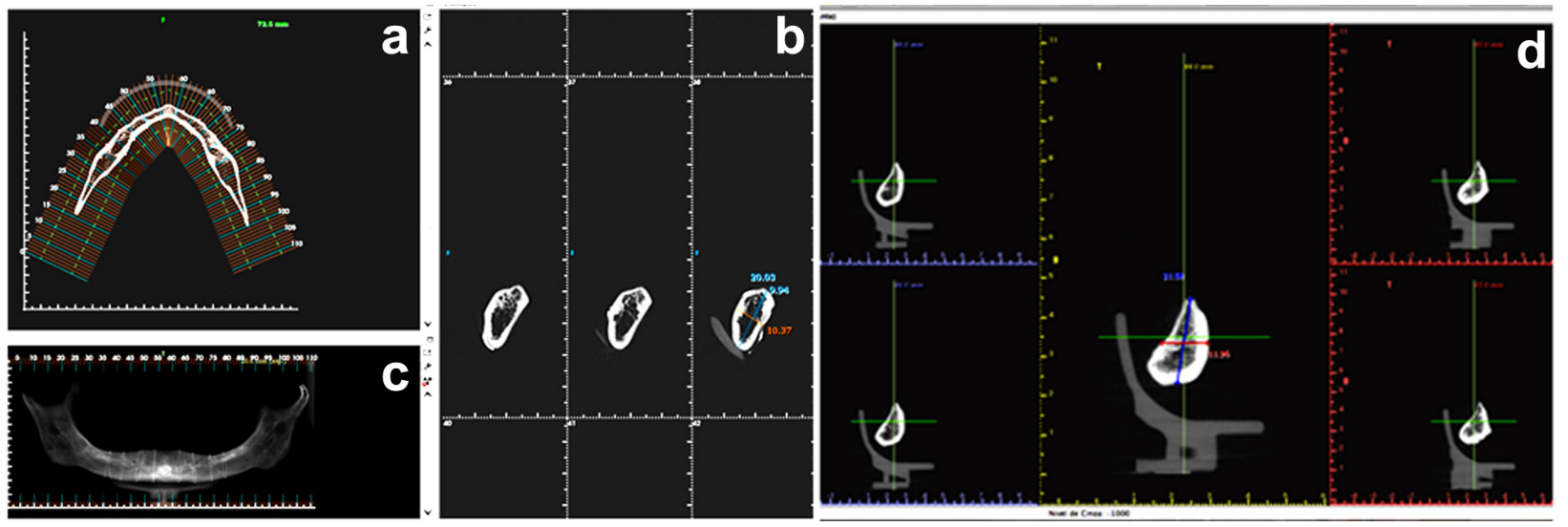

Figure 3 - Dry human mandible manually measured. Operator interface of Imaging Studio® (Anne Solutions, São Paulo, SP, Brazil) software package showing the mandible in axial (a), panoramic (b) and parasagittal (c) views, and Implant Viewer ${ }^{\circledR}($ Anne Solutions, São Paulo, SP, Brazil) software package showing the mandible in the parasagittal view through the highlighted control acquisition parameters $(\mathbf{d})$.

consisted of the distance between the grooves on the upper and the lower surfaces of the mandible, while the width consisted of the distance between the grooves on the vestibular/buccal and lingual surfaces. The distance from the alveolar ridge to the mandibular canal considered the uppermost cortical surface of both the ridge and the canal.

\section{STATISTICS}

Intra and inter-examiner agreement was performed repeating the measurements 3 times by the main examiner (intra) and by a second examiner included in the research (inter) at this stage. The measurements were repeated using the 2 software packages and with the digital caliper within an interval of 1 week. Intraclass Correlation Coefficient (ICC) was applied to assess intra- and inter-examiner reliability.

Data normality was assessed with ShapiroWilk test and the homogeneity of variance with Levene's test. Student's t-test was used to compare measurements between MSCT and CBCT, and between MSCT/CBCT and the digital caliper. Analysis of Variance (ANOVA) followed by post-hoc Dunnet's test was used to compare the measurements obtained with MSCT/CBCT with the 2 software packages and the measurements taken with the digital caliper. All the statistical tests were performed using SPSS ${ }^{\circledR}\left(\right.$ IBM $^{\circledR}$, New York, NY, USA) software package with a significance rate 0.05 .

\section{RESULTS}

ICC test indicated excellent examiner agreement, with outcomes ranging from 0.82 to 0.98 (Hallgren 2012).

The mean values for mandible height, width and distance from the alveolar ridge to the mandible canal were $20.43,10.98,8.65 \mathrm{~mm}$. Student's t-test did not reveal differences statistically significant ( $p>0.05$ ) comparing the measurements obtained with CBCT and MSCT with the reference measurement approach (digital caliper) (Table I).

Lack of differences statistically significant ( $>0$.05) was also found applying Student's t-test to compare the measurements obtained with each software package and the measurements obtained with the digital caliper (Table II).

The Analysis of Variance did not show differences statistically significant $(p>0.05)$ comparing the software packages separately according to each measuring approach (Table III). 
TABLE I

Student's t-test outcomes for the comparison of measuring approaches used in the present study.

\begin{tabular}{|c|c|c|c|c|}
\hline Distance measured & Measuring approach & Mean (mm) & SD & $\mathbf{p}$ \\
\hline \multirow{2}{*}{ Mandible height } & Digital caliper & 20.43 & 2.96 & \multirow{2}{*}{0.93} \\
\hline & CBCT & 20.50 & 2.92 & \\
\hline \multirow{2}{*}{ Mandible width } & Digital caliper & 10.98 & 1.66 & \multirow{2}{*}{0.93} \\
\hline & $\mathrm{CBCT}$ & 10.95 & 1.50 & \\
\hline \multirow{2}{*}{ Alveolar ridge - Mandible canal } & Digital caliper & 8.65 & 2.66 & \multirow{2}{*}{0.88} \\
\hline & CBCT & 8.55 & 2.41 & \\
\hline \multirow{2}{*}{ Mandible height } & Digital caliper & 20.43 & 2.96 & \multirow{2}{*}{0.95} \\
\hline & MSCT & 20.48 & 2.90 & \\
\hline \multirow{2}{*}{ Mandible width } & Digital caliper & 10.98 & 1.66 & \multirow{2}{*}{0.95} \\
\hline & MSCT & 10.95 & 1.39 & \\
\hline \multirow{2}{*}{ Alveolar ridge - Mandible canal } & Digital caliper & 8.65 & 2.66 & \multirow{2}{*}{0.75} \\
\hline & MSCT & 8.42 & 2.63 & \\
\hline \multirow{2}{*}{ Mandible height } & $\mathrm{CBCT}$ & 20.50 & 2.925 & \multirow{2}{*}{0.97} \\
\hline & MSCT & 20.48 & 2.907 & \\
\hline \multirow{2}{*}{ Mandible width } & $\mathrm{CBCT}$ & 10.95 & 1.504 & \multirow{2}{*}{0.98} \\
\hline & MSCT & 10.95 & 1.394 & \\
\hline \multirow{2}{*}{ Alveolar ridge - Mandible canal } & CBCT & 8.55 & 2.417 & \multirow{2}{*}{0.82} \\
\hline & MSCT & 8.42 & 2.630 & \\
\hline
\end{tabular}

CBCT: cone-Beam computed tomography; MSCT: multislice computed tomography; mm: millimeter; SD: standard deviation; p: p-value considering significance rate of 0.05 .

TABLE II

Student's t-test outcomes for the comparison of software packages used in the present study.

\begin{tabular}{|c|c|c|c|c|}
\hline Distance measured & Measuring approach & Mean (mm) & SD & $\mathbf{p}$ \\
\hline \multirow{2}{*}{ Mandible height } & Digital Caliper & 20.43 & 2.96 & \multirow{2}{*}{0.98} \\
\hline & Imaging Studio $^{\circledR}$ & 20.45 & 2.91 & \\
\hline \multirow{2}{*}{ Mandible width } & Digital Caliper & 10.98 & 1.66 & \multirow{2}{*}{0.87} \\
\hline & Imaging Studio $^{\circledR}$ & 10.91 & 1.39 & \\
\hline \multirow{2}{*}{ Alveolar ridge - Mandible canal } & Digital Caliper & 8.65 & 2.66 & \multirow{2}{*}{0.94} \\
\hline & Imaging Studio $^{\mathbb{R}}$ & 8.70 & 2.55 & \\
\hline \multirow{2}{*}{ Mandible height } & Digital Caliper & 20.43 & 2.96 & \multirow{2}{*}{0.90} \\
\hline & Implant Viewer $^{\circledR}$ & 20.53 & 2.91 & \\
\hline \multirow{2}{*}{ Mandible width } & Digital Caliper & 10.98 & 1.66 & \multirow{2}{*}{0.98} \\
\hline & Implant Viewer $^{\mathbb{R}}$ & 10.99 & 1.50 & \\
\hline \multirow{2}{*}{ Alveolar ridge - Mandible canal } & Digital Caliper & 8.65 & 2.66 & \multirow{2}{*}{0.59} \\
\hline & Implant Viewer $^{\circledR}$ & 8.27 & 2.48 & \\
\hline \multirow{2}{*}{ Mandible height } & Imaging Studio $^{\circledR}$ & 20.45 & 2.91 & \multirow{2}{*}{0.90} \\
\hline & Implant Viewer $^{\circledR}$ & 20.53 & 2.91 & \\
\hline \multirow{2}{*}{ Mandible width } & Imaging Studio $^{\circledR}$ & 10.91 & 1.39 & \multirow{2}{*}{0.81} \\
\hline & Implant Viewer $^{\circledR}$ & 10.99 & 1.50 & \\
\hline \multirow{2}{*}{ Alveolar ridge - Mandible canal } & Imaging Studio $^{\circledR}$ & 8.70 & 2.55 & \multirow{2}{*}{0.45} \\
\hline & Implant Viewer $^{\circledR}$ & 8.27 & 2.48 & \\
\hline
\end{tabular}

Imaging Studio $^{\circledR}$ (Anne Solutions ${ }^{\circledR}$, São Paulo, SP, Brazil); Implant Viewer ${ }^{\circledR}$ (Anne Solutions ${ }^{\circledR}$, São Paulo, SP, Brazil); mm: millimeter; SD: standard deviation; $\mathrm{p}$ : $\mathrm{p}$-value considering significance rate of 0.05 . 
TABLE III

Analysis of Variance for the comparison of measuring approaches considering each software package separately.

\begin{tabular}{|c|c|c|c|c|}
\hline Distance measured & Measuring approach & Mean (mm) & SD & $\mathbf{p}$ \\
\hline \multirow{5}{*}{ Mandible height } & Digital Caliper & 20.43 & 0.96 & \multirow{5}{*}{1.00} \\
\hline & CBCT - Imaging Studio & 20.46 & 0.97 & \\
\hline & MSCT - Imaging Studio & 20.45 & 0.92 & \\
\hline & $\mathrm{CBCT}$ - Implant Viewer & 20.54 & 0.94 & \\
\hline & MSCT - Implant Viewer & 20.52 & 0.96 & \\
\hline \multirow{5}{*}{ Mandible width } & Digital Caliper & 10.98 & 1.66 & \multirow{5}{*}{0.93} \\
\hline & CBCT - Imaging Studio* & 10.95 & 1.50 & \\
\hline & MSCT - Imaging Studio & 10.87 & 1.30 & \\
\hline & CBCT - Implant Viewer & 10.94 & 1.53 & \\
\hline & MSCT - Implant Viewer & 11.04 & 1.50 & \\
\hline \multirow{5}{*}{ Alveolar ridge - mandible canal } & Digital Caliper & 8.65 & 2.66 & \multirow{5}{*}{0.87} \\
\hline & CBCT - Imaging Studio & 8.75 & 2.55 & \\
\hline & MSCT - Imaging Studio & 8.65 & 2.62 & \\
\hline & CBCT - Implant Viewer* & 8.35 & 2.32 & \\
\hline & MSCT - Implant Viewer* & 8.20 & 2.68 & \\
\hline
\end{tabular}

Imaging Studio $^{\circledR}$ (Anne Solutions ${ }^{\circledR}$, São Paulo, SP, Brazil); Implant Viewer ${ }^{\circledR}$ (Anne Solutions ${ }^{\circledR}$, São Paulo, SP, Brazil); mm: millimeter; SD: standard deviation; p: p-value considering significance rate of 0.05; *: Based on Dunnett's outcomes all the approaches converged to resemble the real value (digital caliper), except for three approaches $\left(^{*}\right)$ which resembled discretely less $(0.95-0.99 / 1.00)$.

The convergence of measurements obtained with the different software and measuring approaches was confirmed by Dunnett's test (Table III).

\section{DISCUSSION}

Over the last decades, CT scanning became one of the main complementary exams used to provide cross-sectional craniofacial images for diagnosis and treatment planning in Implantology (Frederiksen 1995, Parnia et al. 2010, Tyndall and Brooks 2000, Naitoh et al. 2010, Rubio Serrano et al. 2008). The vast use of CT in Dentistry led to need for constant assessment on the calibration of software tools for linear measurements.

To set up an adequate research design towards the investigation of linear measurements, mandible positioning was standardized for stabilization during the image acquisition. The concern with object positioning is justified on potential image alterations (due to head movement) that may occur on the spatial position in the focus point of the CT
(El-Beialy et al. 2011). To overcome positioning errors, the mandibles used in the present study were fixed in the CT device over a Styrofoam plate. Clearly, an advantage of the present study relies on the use of dry human mandibles instead of images from living patients, as the first are not subjects to voluntary or involuntary movements when stabilized properly.

Once positioned, the mandibles were scanned in CBCT and MSCT. The comparison of linear measurement accuracy between CBCT and MSCT was previously performed and reported in the literature (Soumalainen et al. 2009, FreireMaia et al. 2017). However, major attention is given to the modality of $\mathrm{CT}$ device itself in face of the software packages used for image analysis. In general, CBCT and MSCT perform similarly concerning linear measurements (Loubele et al. 2008). Similarly, the present study confirmed the performance of CBCT and MSCT based on the lack of differences statistically significant $(p>0.05)$ 
between these CT modalities (Figure 1). However, the lack of differences statistically significant between $\mathrm{CT}$ does not guarantee reliability. Based on that, the comparison of CT measurements with a reference measurement (digital caliper) was performed. Accordingly, no differences statistically significant ( $p>0.05)$ were observed (Table I). The clinical significance of these findings remains on the reliable use of CBCT and MSCT scans for dental purposes - especially allowing linear measurements.

Once scanned, the mandibles are registered three-dimensionally as DICOM files, which may be analyzed with a variety of software available. Following the methodological set up, the present study also aimed to compare software packages. Kamburoğlu et al. 2009, addressed the important role of software packages and computer devices in the outcomes of radiographic linear measuring. Currently, the literature hampers the investigation of imaging software, as a great part of the studies published lack identification information (e.g., version, manufacturer and configuration) of the software packages used. Concerning on the software performance, Maloney et al. (2011) analyzed compared SimPlant 3D Pro ${ }^{\circledR}$ software (Materialize $^{\circledR}$, Leuven, Belgium) with the original i-Cat ${ }^{\circledR}$ software (Imaging Sciences International ${ }^{\circledR}$, Hatfield, PA, USA) verifying no difference statistically significant. Considering the three distances measured in the present study, namely the mandible height, width and distance from the alveolar ridge to the mandible canal, none reached differences statistically significant $(p>0.05)$ between software packages (Table II). Yet the measurements taken with the software were also not different statistically ( $p>0.05)$ from the measurements taken with the digital caliper (Table II). These outcomes validate the use of both software for image analysis and treatment planning.

Regarding the high inter- and intra-examiner reproducibility achieved, our results are similar to most studies in the literature, which show that images from CBCT and MSCT software packages lead to high reproducibility of results. The examiner agreement was especially higher for measuring long distances (MH), which reflect the application of software packages for planning dental implants in the posterior region of the mandible, which is a risk area for nerve injury during surgical approaches (Givol et al. 2013).

In light of these results, it is important to accredit both types of tomography used and the two software programs employed in this study for diagnosis and planning of dental implants. Future studies should take into account the alterations introduced when applying filters and when using other software packages. Additionally, large samples of both maxilla and mandible must be investigated and confronted with the existing literature.

\section{CONCLUSIONS}

Measurements of anatomic distances with both CBCT and MSCT software packages revealed high accuracy when compared with distances measured with a digital caliper. The present study points towards the effectiveness and reliability of CBCT and MSCT with the respective software packages tested in the present study for planning dental implants in the routine of Dentistry.

\section{REFERENCES}

BOLLIGER S, THALI M, JACKOWSKI C, AGHAYEV E, DIRNHOFER R AND SONNENSCHEIM M. 2005. Postmortem non-invasive virtual autopsy: death by hanging in a car. J Forensic Sci 50: 455-460.

BOLLIGER SA, THALI MJ, AGHAYEV E, JACKOWSKI C, VOCK P, DIRNHOFER R AND CHRISTE A. 2007. Postmortem noninvasive virtual autopsy: extrapleural hemorrhage after blunt thoracic trauma. Am J Forensic Med Pathol 28: 44-47.

DEGUCHI T, NASU M, MURAKAMI K, YABUUCHI T, KAMIOKA H AND TAKANO-YAMAMOTO T. 2006. Quantitative evaluation of cortical bone thickness with 
computed tomographic scanning for orthodontic implants. Am J Orthod Dentofacial Orthop 129: 721.e7-721.e12.

DENIZ MA, DENIZ ZT, ADIN ME, AKIL F, TURMAK M, URAKCI Z, CETINCAKMAK MG AND GOYA C. 2017. Detection of incidental pulmonary embolism with multi-slice computed tomography in cancer patients. Clin Imaging 41: 106-111.

DREISEIDLER T, TANDON D, KREPPEL M, NEUGEBAUER J, MISCHKOWSKI RA, ZINSER MJ AND ZÖLLER JE. 2012. CBCT device dependency on the transfer accuracy from computer-aided implantology procedures. Clin Oral Implants Res 23: 1089-1097.

EL-BEIALY AR, FAYED MS, EL-BIALY AM AND MOSTAFA YA. 2011. Accuracy and reliability of conebeam computed tomography measurements: Influence of head orientation. Am J Orthod Dentofacial Orthop 140: 157-165.

FREDERIKSEN NL. 1995. Diagnostic imaging in dental implantology. Oral Surg Oral Med Oral Pathol Oral Radiol Endod 80: 540-554.

FREIRE-MAIA B, MACHADO VD, VALERIO CS, CUSTÓDIO AL, MANZI FR AND JUNQUEIRA JL. 2017. Evaluation of the accuracy of linear measurements on multi-slice and cone beam computed tomography scans to detect the mandibular canal during bilateral sagittal split osteotomy of the mandible. Int J Oral Maxillofac Surg 46: 296-302.

GARCIA B, PENARROCHA M, MARTÍ E, MARTÍNEZ JM AND GAY-ESCODA C. 2008. Periapical surgery in maxillary premolars and molars: analysis in terms of the distance between the lesion and the maxillary sinus. J Oral Maxillofac Surg 66: 1212-1217.

GIVOL N, PELEG O, YAROM N, BLINDER D AND LAZAROVICI TS. 2013. Inferior alveolar neurosensory deficiency associated with placement of dental implants. J Periodontol 84: 495-501.

GOLUBOVIC V, MIHATOVIC I, BECKER J AND SCHWARZ F. 2012. Accuracy of cone-beam computed tomography to assess the configuration and extent of ligature-induced peri-implantitis defects. A pilot study. Oral Maxillofac Surg 16: 349-354.

HALLGREN KA. 2012. Computing inter-rater reliability for observational data: an overview and tutorial. Tutor Quant Methods Psychol 8: 23-34.

KAMBUROĞLU K, KILIÇ C, OZEN T AND YÜKSEL SP. 2009. Measurements of mandibular canal region obtained by cone-beam computed tomography: a cadaveric study. Oral Surg Oral Med Oral Pathol Oral Radiol Endod 107: e34-42.

KIM MK, KANG SH, LEE EH, LEE SH AND PARK W. 2012. Accuracy and validity of stitching sectional cone beam computed tomographic images. J Craniofac Surg 23: 1071-1076.
LARHEIM TA, ABRAHAMSSON AK, KRISTENSES M AND ARVIDSSON LZ. 2015. Temporomandibular joint diagnositcs using CBCT. Dentomaxillofac Radiol 44: 20140235.

LOUBELE M, VAN ASSCHE N, CARPENTIER K, MAES F, JACOBS R, VAN STEENBERGHE D AND SUETENS P. 2008. Comparative localized linear accuracy of smallfield cone-beam CT and multislice CT for alveolar bone measurements. Oral Surg Oral Med Oral Pathol Oral Radiol Endod 105: 512-518.

LUND H, GRÖNDAHL K AND GRÖNDAHL HG. 2009. Accuracy and precision of linear measurements in cone beam computed tomography Accuitomo tomograms obtained with different reconstruction techniques. Dentomaxillofac Radiol 38: 379-386.

MALONEY K, BASTIDAS J, FREEMAN K, OLSON TR AND KRAUT RA. 2011. Cone beam computed tomography and SimPlant materialize dental software versus direct measurement of the width and height of the posterior mandible: an anatomic study. J Oral Maxillofac Surg 69: 1923-1929.

MOURA PM, LIMA LV, FARIA MDB AND GUTFILEN B. 2009. Rapid maxillary expansion: evaluation of two methods of 3D reconstruction by means of a laboratorial model. Rev Dent Press Ortodon Ortop Facial 14: 90-93.

NAITOH M, AIMIYA H, HIRUKAWAAAND ARIJI E. 2010. Morphometric analysis of mandibular trabecular bone using cone beam computed tomography: an in vitro study. Int J Oral Maxillofac Implants 25: 1093-1098.

OBAYASHI N, ARIJI Y, GOTO M, IZUMI M, NAITOH M, KURITA K, SHIMOZATO K AND ARIJI E. 2004. Spread of odontogenic infection originating in the maxillary teeth: computerized tomographic assessment. Oral Surg Oral Med Oral Pathol Oral Radiol Endod 98: 223-231.

PALOMO L AND PALOMO JM. 2009. Cone Beam Ct for diagnosis and treatment planning in trauma cases. Dent Clin North Am 53: 717-727.

PARNIA F, FARD EM, MAHBOUB F, HAFEZEQORAN A AND GAVGANI FE. 2010. Tomographic volume evaluation of submandibular fossa in patients requiring dental implants. Oral Surg Oral Med Oral Pathol Oral Radiol Endod 109: e32-36.

PENG N, WANG X, ZHANG Z, FU S, FAN J AND ZHANG Y. 2016. Diagnosis value of multi-slice spiral CT in renal trauma. J Xray Sci Technol 24: 649-655.

PINSKY HM, DYDA S, PINSKY RW, MISCH KA AND SARMENT DP. 2006. Accuracy of three-dimensional measurements using cone-beam CT. Dentomaxillofac Radiol 35: 410-416.

PRIMO BT, PRESOTTO AC, DE OLIVEIRA HW, GASSEN HT, MIGUENS SA, SILVA AN AND HERNANDEZ PA. 2012. Accuracy assessment of prototypes produced using 
multi-slice and cone-beam computed tomography. Int J Oral Maxillofac Surg 41: 1291-1295.

PUENTES K, TAVEIRA F, MADUREIRA AJ, SANTOS A AND MAGALHÃES T. 2009. Three-dimensional reconstitution of bullet trajectory in gunshot wounds: a case report. J Forensic Leg Med 16: 407-410.

RUBIO SERRANO M, ALBALAT ESTELA S AND PENARROCHA DIAGO M. 2008. Software applied to oral implantology: update. Med Oral Patol Oral Cir Bucal 13: e661-665.

SELDEN HS. 1999. Endo-Antral syndrome and various endodontic complications. J Endod 25: 389-393.
SUOMALAINEN A, KILJUNEN T, KASER Y, PELTOLA J AND KORTESNIEMI M. 2009. Dosimetry and image quality of four dental cone beam computed tomography scanners compared with multislice computed tomography scanners. Dentomaxillofac Radiol 38: 367-378.

TEJASWI KB AND PERIYA EAH. 2013. Virtopsy (virtual autopsy): A new phase in forensic investigation. J Forensic Dent Sci 5: 146-148.

TYNDALL DA AND BROOKS SL. 2000. Selection criteria for dental implant site imaging: a position paper of the American Academy of Oral and Maxillofacial radiology. Oral Surg Oral Med Oral Pathol Oral Radiol Endod 89: 630-637. 